\title{
Структурно-функциональные особенности новых аллелей гена цветения мягкой пшеницы VRN-B3
}

Бережная А.A. ${ }^{* 1,2}$ студент, Киселева А.А. ${ }^{2}$ к.б.н., Салина Е.А. ${ }^{2}$ д.б.н. ${ }^{1}$ Новосибирский государственный университет, Новосибирск, Россия;

${ }^{2}$ Институт иитологии и генетики СО РАН, Новосибирск, Россия.

*e-mail: al.berezhnaya1@gmail.com

Проведено генотипирование коллекции яровой мягкой пшеницы для определения генетического разнообразия по основным детерминантам времени колошения. Выявлено два ранее не описанных мутантных аллеля гена

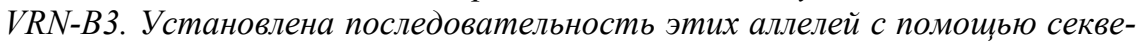
нирования, а также проведена их аннотация.

Ключевые слова: мягкая пшеница, генотипирование, новый аллель, время колошения, VRN-B3.

\section{Functional and structural characterization of new $V R N-B 3$ alleles in hexaploid bread wheat}

Berezhnaya A.A. ${ }^{* 1,2}$, Kiseleva A.A. ${ }^{2}$, Salina E.A. ${ }^{2}$

${ }^{1}$ Novosibirsk State University, Novosibirsk, Russia; ${ }^{2}$ Institute of Cytology and Genetics SB RAS, Novosibirsk, Russia.

Genotyping of common wheat collection was conducted to analyze genetic diversity of the most important wheat heading time regulators. Two previously not described mutant alleles of VRN-B3 gene were sequenced and annotated.

Key words: common wheat, genotyping, new alleles, heading time, VRN-B3.

Время колошения - сложный признак, от которого зависит адаптационная способность растения и его шансы на репродуктивный успех. Одним из ключевых генов, регулирующих этот признак, является $V R N-B 3 . V R N-B 3$ картирован на коротком плече 7В хромосомы, на $1 \mathrm{cM}$ дистальнее маркера ABC158 и на 5 сM проксимальнее микросателлитного маркера GWM569 [3]. На его экспрессию оказывают влияние гены ответа на яровизацию $(V R N-1$ и $V R N-2)$, гены чувствительности к фотопериоду ( $P P D-1)$, гены циркадных ритмов и некоторые другие гены.

Помимо интактного рецессивного аллеля $v r n-B 3$, на данный момент известно 3 мутантных аллеля $V R N-B 3$. Мутации затрагивают промоторную область изучаемого гена и приводят либо к сниженной, либо, напротив, повышенной экспрессии. Аллель Vrn-B3a обуславливает раннее цветение, его экспрессия усилена в результате инсерции ретроэлемента протяженностью 
5300 п.н. в промоторной области (Yan et al., 2006). Аллель Vrn-B3c содержит такую же инсерцию, а также дополнительные делеции 4 п.н. (в ретроэлементе) и 20 п.н. (ранее ретроэлемента), его экспрессия несколько ниже, чем у $V r n-B 3 a$ [1]. Другой аллель Vrn-B3b, содержащий инсерцию 890 п.н. в промоторной области, характеризуется значительным снижением экспрессии, и, таким образом, обуславливает задержку колошения [1].

Следует заметить, все описанные аллели очень редко встречается у культивируемых сортов $[1,2]$. Цель данной работы - выявление новых аллелей гена $V R N-B 3$ и изучение их структурно-функциональной организации.

В исследование были отобраны 93 сорта мягкой пшеницы отечественной селекции, адаптированных к условиям Западной Сибири и Урала, и различающиеся по времени колошения от среднеранних до среднепоздних. Эти образцы были генотипированы с использованием специально разработанных праймеров к гену $V R N-B 3$ для того, чтобы изучить аллельное разнообразие гена в популяции. Было показано, что у некоторых сортов длина ПЦРпродуктов отличается от ожидаемой (больше, чем у интактной последовательности $V r n-B 3$, но не соответствует ни одному известному аллелю этого гена). Обнаруженные варианты гена были отсеквенированы, также была проведена работа по аннотированию этих последовательностей.

Выявлен один сорт с инсерцией 1617 п.н., и 10 сортов с инсерцией 160 п.н. (эти аллели были обозначены как $V R N-B 3 d$ и $V R N-B 3 e$, соответственно). Инсерции расположены за 85 п.н. и 881 п.н. до сайта начала транскрипции (рисунок). На основании последовательностей описанных аллелей разработаны ПЦР маркеры, которые можно использовать для их обнаружения.

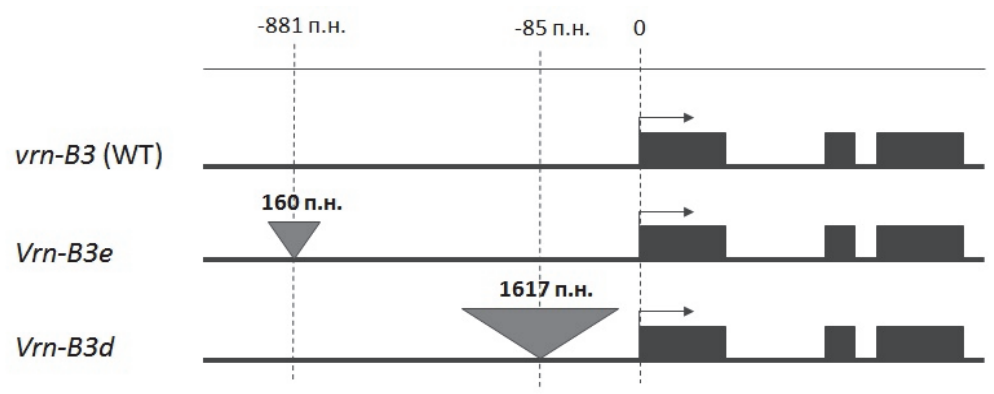

Рисунок. Расположение инсерций в промоторной области гена.

Инсерция аллеля $V R N-B 3 d$ представляет собой ретроэлемент, фланкированный повторяющимися элементами протяженностью 250 п.н., высоко гомологичный неаннотированному ретротранспозону Hordeum vulgare L. Последовательность инсерции $V R N-B 3 e$ демонстрирует высокую гомологию к ряду участков генома пшеницы, на данный момент не аннотированых. 
Таким образом, в ходе данной работы было идентифицировано и описано два новых аллеля гена $V r n-B 3$, в настоящий момент ведутся работы по оценке их фенотипического эффекта.

Благодарности: Данная работа была выполнена при поддержке РФФИ № 20-016-00059.

\section{Список литературы}

1. Chen F. [и др.]. Molecular characterization of vernalization and response genes in bread wheat from the Yellow and Huai Valley of China // BMC Plant Biology. 2013. № 1 (13).

2. Iqbal M., Shahzad A., Ahmed I. Allelic variation at the Vrn-A1, Vrn-B1, Vrn-D1, Vrn-B3 and Ppd-D1a loci of Pakistani spring wheat cultivars // Electronic Journal of Biotechnology. 2011. № 1 (14). C. 1-9.

3. Yan L. [и др.]. The wheat and barley vernalization gene VRN3 is an orthologue of FT // Proceedings of the National Academy of Sciences of the United States of America. 2006. № 51 (103). C. 19581-19586.

DOI 10.18699/GPB2020-12

\section{Скриниг генотипов риса с окрашенным перикарпом на содержание амилозы}

Беркимбай X.A. ${ }^{1,2 *}$, PhD докторант, м.н.с.; Усенбеков Б.Н. ${ }^{2}$, к.б.н., ассои. профессор; Гаркуша С.В. ${ }^{3}$, д.с-х.н.

${ }^{1}$ Казахский национальный аграрный университет, г. Алматы, Казахстан; ${ }^{2}$ Институт биологии и биотехнологии растений, г. Алматы. Казахстан; ${ }^{3}$ Федеральный научный центр риса, г. Краснодар, Россия.

*e-mail:b.horlan@bk.ru

Крахмал является полисахаридом зерновки риса состоящая из большого количества остатков глюкозы, звенья которого соединенные гликозидными связями. Крахмал в рисе представлен в виде смеси двух фракиии полисахаридов - амилозы и амилопектина. Биохимический анализ содержания амилозы $F_{6}-F_{7}$ гибридов с окрашенным перикарпом показал, что содержание амилозы у исследуемых образиов риса колеблется от $0 \%$ до 24,5\%.

Ключевые слова: рис с окрашенным перикарпом, амилоза, восковидный, глютинозный, Wх ген, гибриды.

\section{Screening of rice genotypes with a colored pericarp for amylose}

Berkimbay Kh.A. ${ }^{1,2}$, Ussenbekov B.N. ${ }^{2}$, Garkusha S.V. ${ }^{3}$

${ }^{1}$ Kazakh National Agrarian University, Almaty, Kazakhstan,

${ }^{2}$ Institute of Plant Biology and Biotechnology, Almaty, Kazakhstan, ${ }^{3}$ Federal Scientific Center for Rice, Krasnodar, Russia. 